\title{
Informações contábeis tempestivas: uma análise dos mecanismos isomórficos do processo de fechamento contábil
}

Timely accounting information: an analysis of the isomorphic mechanisms of the month end closing process

Información contable oportuna: un análisis de los mecanismos isomorfos del proceso de cierre contable

\section{Gisele Fernanda Salvador}

Mestre em Ciências Contábeis na Fecap - Fundação Escola de Comércio Álvares Penteado Endereço: Rua da Saudade, N॰16, Casa 16, Bairro Bom Pastor

CEP: 68170-000 - Juruti/PA - Brasil

E-mail: gisele.salvador@alcoa.com

Telefone: (11) 99599-8337

\section{Claudio Parisi}

Doutor em Controladoria e Contabilidade na Universidade de São Paulo

Professor-Pesquisador do Mestrado em Ciências Contábeis da Fecap - Fundação Escola de Comércio Álvares Penteado

Endereço: Av. Liberdade, n॰ 532, Bairro Liberdade

CEP: 01502-001 - São Paulo/Sp - Brasil

E-mail: claudio.parisi@fecap.br

Telefone: (11) 3272-2343

\section{Ivam Ricardo Peleias}

Doutor em Controladoria e Contabilidade na Universidade de São Paulo

Professor-Pesquisador do Mestrado em Ciências Contábeis da Fecap - Fundação Escola de Comércio Álvares Penteado

Endereço: Av. Liberdade, n॰ 532, Bairro Liberdade

CEP: 01502-001 - São Paulo/SP - Brasil

E-mail: ivamrp@fecap.br

Telefone: (11) 3272-2343

\section{Reinaldo Guerreiro}

Doutor em Controladoria e Contabilidade na Universidade de São Paulo

Professor Titular do Departamento de Contabilidade e Atuária da FEA/USP

Endereço: Av. Prof. Luciano Gualberto, no 908, Bairro Butantã

CEP: 05508-010 - São Paulo/SP - Brasil

E-mail: reiguerr@usp.br

Telefone: (11) 3091-5820

Artigo recebido em 16/08/2017. Revisado por pares em 28/05/2018. Reformulado em 20/09/2018. Recomendado para publicação em 28/09/2018 por Carlos Eduardo Facin Lavarda (Editor-Chefe). Publicado em 19/12/2018. 


\title{
Resumo
}

Organizações preocupadas com sua continuidade e crescimento despendem considerável esforço para obter eficácia e conferir eficiência aos sistemas de controle gerencial. Esta pesquisa teve como objetivo conhecer a influência dos mecanismos isomórficos no processo de fechamento contábil tempestivo. É um estudo de caso acerca dos processos de uma organização multinacional representativa no segmento em que atua. Foram realizadas entrevistas, aplicados questionários e analisados filmes institucionais, para identificar e avaliar a ação das contribuições por meio de exames dos três mecanismos do isomorfismo em relação ao fechamento contábil tempestivo. Constatou-se que não há relação entre os três mecanismos do isomorfismo. Foi identificada uma influência relativa do isomorfismo mimético, por conta do Sistema Toyota de Produção, uma forte influência do mecanismo coercitivo por influência da matriz em relação à tempestividade do fechamento contábil, não tendo sido identificada evidência relativa à influência do isomorfismo normativo.

Palavras-chave: Isomorfismo; Teoria institucional; Contabilidade gerencial; Fechamento Contábil

\begin{abstract}
Considering the present organizational context in which there is an intensification of the efforts made by organizations aiming to provide higher eficience to the management control systems, this research is presented. Such work aims to understand the influence of a isomorphic mechanism on the timely closing process in relation to the performance management. The research methodology applied on this examination consists in a case study in a large representative multinational organization in the segment in which it operates, through interviews, questionnaires and video. Finally, the findings suggest that there is no relation among the three isomorphic mechanisms to the extent that it was identified that only the coercive and mimetic mechanisms influence the timely closing process, while there is no evidence on the influence of normative mechanism regarding the such process.
\end{abstract}

Keywords: Isomorphism; Institutional theory; Management accounting; Month end closing

\section{Resumen}

Las organizaciones que se preocupan por su continuidad y crecimiento se esfuerzan considerablemente para lograr la eficacia y otorgarles eficiencia a los sistemas de control de gestión. El objetivo de esta investigación fue conocer la influencia de los mecanismos del isomorfismo en el proceso de cierre contable oportuno. Se trata de un estudio de caso acerca de los procesos de una organización multinacional representativa de la industria en la que actúa. Se llevaron a cabo diferentes entrevistas, se aplicaron encuestas y se analizaron videos institucionales, para identificar y evaluar la acción de las contribuciones mediante el análisis de los tres mecanismos del isomorfismo con relación al cierre contable oportuno. Se constató que no hay relación entre los tres mecanismos del isomorfismo. Se identificó una influencia relativa del isomorfismo mimético debido al Sistema Toyota de Producción, una fuerte influencia del mecanismo coercitivo por influjo de la matriz, con relación a la tempestividad del cierre contable, y no se identificó evidencia científica relacionada a la influencia del isomorfismo normativo.

Palabras clave: Isomorfismo; Teoría institucional; Contabilidad de gestión; Cierre contable

\section{Introdução}

A divulgação das demonstrações contábeis possui relevante significado para certos grupos de usuários da informação contábil. Kirch, Lima e Terra (2012, p. 174) concluíram que a informação contábil afeta os preços das ações; portanto, apresenta relevância para o mercado de capitais. A utilidade da informação contábil está relacionada à sua natureza, ao conteúdo e 
ao momento em que é divulgada, para que atenda aos atributos da tempestividade, tais como velocidade e frequência dos relatórios, definidos por Moores e Yuen (2001, p. 355 e 357).

Informações confiáveis e de qualidade podem deixar de influir no processo decisório se não divulgadas no momento apropriado. Assim, organizações comprometidas com melhores práticas de governança corporativa, e sob maior escrutínio do mercado, estão mais dispostas à divulgação das demonstrações contábeis tempestivamente (KIRCH; LIMA; TERRA, 2012 p. 174). Organizações em ambiente competitivo publicam suas informações tempestivamente na tentativa de fornecer informações ao mercado. Nessas condições, ter um processo de fechamento contábil que assegure a apuração dos resultados no primeiro dia útil de cada mês agrega valor aos atributos de qualidade das informações contábeis (ALMEIDA, 2010, p.142).

As pressões existentes no ambiente competitivo e o alto grau de conectividade e complexidade dos sistemas de informações globais, aliado à rapidez das mudanças, levam as organizações à incerteza, fazendo com que sejam impelidas a se tornarem cada vez mais parecidas. No contexto das relações empresariais, o comportamento de uma organização é condicionado ou determinado pelo conjunto de relações mantidas em seu campo organizacional. As organizações estão se tornando cada vez mais similares com outras com as quais compartilham o mesmo campo organizacional (DIMAGGIO; POWELL, 2005, p. 76).

$\mathrm{O}$ estudo das relações e do ambiente no qual as organizações se inserem pode ser encontrado na Teoria Institucional, por meio da Nova Sociologia Institucional. O conceito de institucionalização não é por definição relacionado a um processo distinto; há vários tipos de processos que podem levar uma organização a mudar sua estrutura para se adequar a um padrão institucional (SCOTT, 1987, p.498). Dimaggio e Powell (2005) distinguiram três mecanismos isomórficos que podem conduzir as organizações à conformidade: coercitivo (regras, leis e sanções), normativo (certificação e aceitação) e mimético (resultante dos padrões de resposta à incerteza) (DIMAGGIO; POWELL, 2005, p. 77).

Ao considerar os mecanismos do isomorfismo mimético, coercitivo e normativo e a utilidade da informação contábil em relação ao tempo em que é divulgada, pretende-se responder à seguinte questão de pesquisa: Como os mecanismos isomórficos influenciam o processo de fechamento contábil para geração de informações contábeis tempestivas em uma organização? O objetivo é conhecer a influência dos mecanismos isomórficos no processo de fechamento contábil tempestivo.

Pretende-se relacionar os três mecanismos de mudança institucional isomórfica apresentados por Dimaggio e Powell (2005), a relevância da tempestividade das informações contábeis, as razões pelas quais uma organização apresenta os números contábeis no primeiro dia útil do mês seguinte e quais foram os sistemas de controles gerenciais usados para que houvesse a antecipação do processo de fechamento, em função da mudança de valores dentro da organização. Com a pesquisa, foi possível aprofundar o conhecimento sobre os mecanismos isomórficos no fechamento contábil para gerar informações tempestivas, além de resgatar uma história de transformação institucional iniciada há mais de 30 anos.

A partir de premissa da relevância da tempestividade das informações contábeis para as organizações, foi feito um estudo de caso em uma organização multinacional, pioneira no mundo no segmento de produção de alumínio primário (lingotes e tarugos), pó de alumínio, alumínio transformado, mineração de bauxita, refino de alumina e energia.

A organização, sediada nos Estados Unidos, foi fundada há mais de 130 anos, atua em 30 países, tem mais de 200 plantas ao redor do mundo e 60 mil funcionários. Usa tecnologia de informação avançada, para disponibilizar, de maneira rápida e segura, as informações contábeis e de mercado para apoiar o processo decisório. A busca constante por melhorias a levou a aprimorar processos, para atingir excelência em seus resultados, um de seus valores organizacionais.

A contribuição obtida é a descrição da influência dos fenômenos isomórficos nas práticas de contabilidade gerencial. Outra contribuição é o foco do estudo no estudo dos três 
mecanismos isomórficos. Durante a pesquisa, houve dificuldade de encontrar materiais específicos que detalhassem o isomorfismo coercitivo, e elementos que permitissem analisar os três mecanismos isomórficos aplicados às informações contábeis. Essa constatação está em linha com os achados de Mizruchi e Fein, (1999), após testarem 160 artigos em revistas norte americanas e concluírem que, em apenas 26 deles, tentaram operacionalizar e testar empiricamente um ou mais componentes da tese de Dimaggio e Powell (2005).

\section{Revisão de Literatura e Estrutura Conceitual}

\subsection{Sistemas de Contabilidade Gerencial}

A modernização pelo avanço tecnológico, a redução no ciclo de vida dos produtos e a globalização dos mercados levam as organizações a investirem em sistemas de informações contábeis mais relevantes e precisos. Os sistemas contábeis devem prover informações tempestivas e acuradas para facilitar o esforço de controlar custos, mensurar e melhorar a produtividade e criar melhorias no processo de produção. A relevância e a confiabilidade das informações dependem da tempestividade de sua divulgação (MOORES; YUEN, 2001, p. 355 e 357).

O uso da informação contábil gerencial dentro da organização é um elemento prioritário no processo decisório. A informação deve ser tempestiva para que seja usada no processo de formulação estratégica (FREZATTI et al., 2007, p. 41). A medição do desempenho lida com a avaliação dos resultados, enquanto a gestão de desempenho lida com a tomada de medidas, baseada nos resultados da avaliação, para garantir que os objetivos sejam alcançados (BRUDAN, 2010, p.111). Na tentativa de descentralizar os objetivos e as tomadas de decisão, a medição de desempenho pode ser dividida em estratégica, operacional e individual. Desse modo, os objetivos são definidos no topo e distribuídos até a base da organização.

Vicente, Major e Pinto (2011) realizaram testes em Portugal e no Reino Unido. Concluíram que as organizações buscam os progressos tecnológicos, para introduzir técnicas de controle de gestão mais avançadas, que permitam obter informação de gestão de natureza financeira ou não financeira, para apoiar as suas decisões. Assim, podem lidar com as pressões cada vez mais competitivas impostas pelo ambiente (VICENTE; MAJOR; PINTO, 2011, p 25).

Um caminho para materializar o progresso tecnológico é a implantação de sistemas ERP (Enterprise Resources Planning). Essa tecnologia permite que a controladoria se envolva menos com tarefas rotineiras e passe a prover maior suporte nas tomadas de decisão, seja para gestores de plantas que precisam de informações sobre a operação diária, seja para executivos que precisam de informações para decisões estratégicas (DAVIS; ALBRIGHT, 2000, p. 447). $\mathrm{O}$ gerenciamento financeiro efetivo requer o uso de sistemas integrados para incorporar atividades de custos e mensuração de desempenho (COLMENARES, 2009, p.3).

As informações geradas pelos sistemas de informações devem possuir determinadas características, como clareza, precisão e rapidez, além de ser direcionadas a um propósito específico (ANNI; KRISMIAJI, 2013, p. 29; MACCARI; SAUAIA, 2006, p. 373). Quanto à definição do conceito de qualidade, quando aplicado ao objeto principal, a informação, não há consenso definitivo (OLETO, 2006, p. 58). A informação pode ser subjetiva quando as preferências de usuários variam, são contingenciais e nem sempre se explicitam de forma adequada em demandas claras e objetivas; ou quando há conflitos entre as preferências e as prioridades de produção que os provedores de informação tendem a estabelecer (PAIM; NEHMY; GUIMARÃES, 1996, p. 113). A qualidade das informações contábeis das organizações também pode ser impactada por premissas como conservadorismo (ALMEIDA et al., 2012, p. 74) e gerenciamento de resultado (ANNI; KRISMIAJI, 2013, p. 29), pois as demonstrações são o resultado de escolhas subjetivas, como estimativas e políticas contábeis. 
Ao considerar que a qualidade das informações contábeis é base para uma medição de desempenho adequada, essas informações devem ter características qualitativas, como relevância, ser entendível, verificável e comparativa, internacionalmente. Com o advento dos softwares de inteligência de negócios (Business Objects, Hyperion, Cognos, etc), que permitem que as organizações tenham acesso a novos níveis de dados integrados, e a relatórios que podem ser customizados de maneiras variadas, a utilização dos indicadores de desempenho está cada vez mais fácil, e sua obtenção cada vez mais rápida. Assim, as demonstrações financeiras estão cada vez mais esquecidas (BRUDAN, 2010, p. 114; WAGNER, 2012, p. 58).

\subsection{Isomorfismo}

O termo instituição denota estabilidade e ordem; porém, não significa que as instituições não sejam objeto de mudanças. Sistemas institucionais são suscetíveis a mudanças por circunstâncias externas ou internas, assim como os processos institucionais podem ser estabelecidos, do topo para a base e da base para o topo. A razão dessas mudanças pode ser explicada por discrepâncias entre sistemas de macro e micro atividades em resposta a circunstâncias locais, por incoerência entre os elementos institucionais, estruturas concorrentes, ou níveis de desempenho abaixo das expectativas (SCOTT, 2008, p.431 e 437).

Elementos institucionais implantados comumente podem surgir dentro da organização, pela imitação de outras similares (ZUCKER; TOLBERT, 1983, p.26), ou de interações. As mudanças resultam de processos que tornam as organizações cada vez mais similares. Essas organizações buscam legitimidade externa, contribuindo para entender relações entre a estrutura organizacional e o ambiente em que estão inseridas; porém, a homogeneidade necessariamente não as torna mais eficientes (DIMAGGIO; POWELL, 2005, p. 81; MACHADO-DA-SILVA; FONSECA, 2010, p.16) argumentam que o isomorfismo é um mecanismo vantajoso para as organizações, já que a similaridade facilita as transações interorganizacionais e favorece o seu funcionamento interno, pela incorporação de regras socialmente aceitas.

A institucionalização é o processo pelo qual as ações são repetidas e assimiladas pelos integrantes de uma organização (SCOTT, 1987, p.495). Resulta dos esforços de atores para chegarem ao fim proposto, e seu sucesso depende do poder relativo dos atores que apoiam, se opõem ou não se esforçam na influência do objetivo proposto (DIMAGGIO, 1988 apud in SCOTT, 2008, p. 431).

O isomorfismo é estudado sob o enfoque da Nova Sociologia Institucional (New Institutional Sociology - NIS), a qual considera que, para assegurarem sua continuidade, as organizações precisam se conformar às normas sociais de comportamento aceitável, além de atingir vários níveis de eficiência produtiva. Esse enfoque aplica-se ao estudo de macro instituições na análise da relação entre a organização e o ambiente em que se inserem, e o comportamento dos atores institucionais, na pesquisa de suas decisões, para aumentar a legitimidade (GUERREIRO et al., 2005, p. 97; GUERREIRO, 2006, p.3). Estratégias racionais para as organizações individualmente podem não ser adotadas por um grande número de outras, mas o fato de essas estratégias serem normativamente sancionadas aumenta a possibilidade de sua adoção em outras organizações (DIMAGGIO; POWELL, 2005, p. 76).

A tentativa de minimizar ou eximir restrições ou incertezas em campos organizacionais gera uma tendência à homogeneidade em termos de estrutura, cultura organizacional e resultados. Essa homogeneização é institucionalizada quando for assimilada e repetida pelos integrantes de uma organização. $\mathrm{O}$ melhor indicador de mudanças isomórficas é a diminuição de variação e diversidade (DIMAGGIO; POWELL, 2005, p 75 e 83).

O processo de homogeneização pode ser definido como isomorfismo, no qual as 
características organizacionais são direcionadas ou impelidas à similaridade das características da população inseridas no mesmo ambiente (DIMAGGIO; POWELL, 2005, p. 76). O isomorfismo é o processo restritivo que força a unidade em uma população a se parecer com outras que enfrentam condições semelhantes; porém, deve-se considerar que a institucionalização de mudanças propostas para atingir a homogeneidade não ocorre apenas pela imposição, pois há conflitos quando os atores sociais competem por poder, recursos ou controle no campo de batalha. Assim, a implantação de ações propícias à mudança pode não implicar em uma alteração imediata, mas em redefinições do arranjo organizacional (CHENG; YU, 2008, p. 334; DIMAGGIO; POWELL, 2005, p. 76).

Dimaggio e Powell (2005, p. 77) distinguiram três mecanismos pelos quais ocorrem mudanças isomórficas e conduzem a conformidade: coercitivo, mimético e normativo. Slack e Hinings (1994, p. 821) realizaram estudos em associações esportivas do Canada e concluíram que os três mecanismos isomórficos são distintos; contudo, reforçam a existência um do outro. Segue na tabela 1, adiante, a relação entre os mecanismos propostos, os indicadores e a base de legitimação entre eles:

Tabela 1 - Relação entre os mecanismos do isomorfismo, indicadores e a legitimação

\begin{tabular}{c|c|c|c}
\hline Mecanismos & Coercitivo & Normativo & Mimético \\
\hline Indicadores & $\begin{array}{c}\text { Regras, leis e } \\
\text { sanções }\end{array}$ & Certificação & Predomínio \\
\hline $\begin{array}{c}\text { Base da } \\
\text { legitimação }\end{array}$ & $\begin{array}{c}\text { Legalmente } \\
\text { sancionada }\end{array}$ & $\begin{array}{c}\text { Moralmente } \\
\text { governada }\end{array}$ & $\begin{array}{c}\text { Culturalmente apoiada, conceitualmente } \\
\text { correta }\end{array}$ \\
\hline
\end{tabular}

Fonte: Adaptado de Scott, (2001 p. 52).

O isomorfismo coercitivo resulta de pressões formais e informais exercidas por uma organização sobre outra que se encontra em condição de dependência, ou até mesmo por expectativas culturais da sociedade. Essas pressões podem ser sentidas como coerção, persuasão ou conluio (DIMAGGIO; POWELL, 2005, p. 77).

As ordens governamentais são um exemplo de isomorfismo coercitivo, pois impõem a conformidade entre os atores afetados, seja individual ou coletivo (SCOTT, 2008, p.430). A existência de um ambiente legal comum afeta vários aspectos do comportamento e da estrutura das organizações, pois há exigência de controles organizacionais apropriados para honrar compromissos legais, como por exemplo, de relatórios contábeis que assegurem a elegibilidade para licitações ou contratos federais. A expansão do domínio do Estado e de outras organizações, racionalizadas às várias arenas da vida social, resultam em organizações mais homogêneas dentro de certo domínio, cada vez mais organizadas em torno de rituais de conformidade com instituições maiores, e cada vez menos integradas por controles de resultados (DIMAGGIO; POWELL, 2005, p. 77).

O isomorfismo coercitivo não resulta necessariamente de escolhas conscientes, pois, diante da escassez de informações, uma ação pode ser efetuada de acordo com normas postuladas socialmente, ao menos para manter a legitimidade da organização em seu campo (MACHADO-DA-SILVA; FONSECA, 2010, p. 15). A imposição de procedimentos e regras padronizados ditados pela matriz pode ocorrer a partir das relações de autoridade, como no caso da adoção por uma subsidiária, ou quando as estruturas são alteradas e impostas em empresas adquiridas (MACHADO-DA-SILVA; FONSECA, 2010, p. 15; SCOTT, 1987, p. 501). Práticas contábeis, avaliações de desempenho e planos orçamentários compatíveis com as políticas da matriz são exemplos de mecanismos padronizados adotados por subsidiárias (DIMAGGIO; POWELL, 2005, p. 78).

$\mathrm{O}$ isomorfismo mimético deriva dos padrões de resposta à incerteza, que encoraja a imitação, quando uma organização toma outra como exemplo, face a um problema com resposta incerta (DIMAGGIO; POWELL, 2005, p. 78). Segundo Machado-da-Silva e Fonseca (2010), 
essa imitação de arranjos estruturais e procedimentos busca reduzir a incerteza causada por problemas tecnológicos, objetivos conflitantes e exigências institucionais. Esses modelos podem ser incorporados indiretamente pela transferência e rotatividade de funcionários, ou diretamente pela contratação de consultorias. Uma organização pode não saber que está sendo imitada, ou pode até mesmo não ter o desejo de ser imitada; porém, essa pode ser uma solução econômica, pois antecipa a identificação de possíveis problemas, e não há a necessidade de iniciar a criação de um modelo desde o estágio inicial (DIMAGGIO; POWELL, 2005, p. 78).

O processo de imitação ocorre sempre que os atores entram em um novo campo social, pois os recém-chegados tendem a imitar os mais experientes. Há dois efeitos sobre o mimetismo: o primeiro é o comportamental, no qual se observa a imitação de outros atores; o segundo é a influência na cognição humana, em que esquemas de percepção e ação são construídos e afetarão as futuras práticas desses atores. Assim, quando novas práticas forem legitimadas, há uma forte tendência de que novos atores a imitem (SIEWEKE, 2014, p 30 e 31).

Machado-da-Silva e Fonseca (2010, p.15) identificaram que, em 1990, o Governo Collor implantou um severo plano econômico-administrativo, que visava, dentre outros fatores, a modernização do parque industrial brasileiro, para aumentar qualidade e produtividade. Todavia, houve o confisco de ativos financeiros e a desindexação da economia, o que levou o Brasil a uma forte recessão, agravada por aumento dos índices inflacionários e das taxas de juros, com a redução da produção industrial e do nível de emprego. As empresas, nesse período, no esforço de aumentar a competitividade no mercado, tentaram reduzir os seus custos.

Nessa pesquisa, os autores investigaram uma empresa familiar, que tentava manter sua competitividade, revelou o redirecionamento de seus investimentos para a modernização do processo produtivo, seguindo uma tendência mimética quando os sócios da empresa visitaram o Japão, Estados Unidos e Alemanha, com o objetivo de aumentar o conhecimento tecnológico e conseguir futuros clientes. Essa ação também visou a uma melhor adaptação às regras do novo plano governamental, para equiparar-se à qualidade internacional e aumentar a produtividade. A combinação das exigências internas e externas levou à implantação de ações modernizadoras, como um programa de planejamento estratégico, um sistema de informações gerenciais alinhado às normas internacionais e a modernização do parque fabril.

O isomorfismo normativo pode ser associado a profissões. As associações profissionais e de certificação contribuem para promulgar regras normativas sobre comportamento organizacional e profissional. Outro meio de propagar regras normativas são as universidades e instituições de treinamento profissional e seleção de pessoal, pois, para determinados cargos, os pré-requisitos são cuidadosamente definidos e invariáveis (BRANDAU et al. 2013, p. 473; DIMAGGIO; POWELL, 2005, p. 80). Ainda que tipos variados de profissionais de uma organização possam diferir uns dos outros, há semelhanças entre seus pares profissionais em outras organizações.

Em vários campos organizacionais, indivíduos que alcançam o topo são praticamente indistinguíveis, pois o processo de seleção é desenhado para não haver variações. A seleção de pessoas ocorre pela contratação de indivíduos de organizações do mesmo segmento, pessoas com alto desempenho de um grupo restrito de instituições de treinamento, ou requerimentos de habilidades atreladas a cargos específicos. Como consequência a essa invariabilidade no processo de seleção, os tomadores de decisões tendem a resolver os problemas de maneira similar, porque os procedimentos estão, normativamente, sancionados e legitimados (DIMAGGIO; POWELL, 2005, p. 80).

A incorporação de conhecimentos oriundos da percepção externa permite que os esquemas interpretativos sejam direcionados à padronização das atividades dentro da estrutura, pela elaboração dos padrões interativos organizacionais (MACHADO-DA-SILVA; FONSECA, 2010, p. 18). Na pesquisa de Brandau et al. (2013, p. 473), a qualificação profissional foi outra característica encontrada no aspecto normativo, em que os programas de 
formação de executivos no Brasil aumentaram após 1990. Isso porque o mercado exigiu melhor qualificação, pois estava em crescente expansão internacional, e influenciou fortemente o intercâmbio de estudantes, contribuindo para o aumento da qualidade da mão de obra especializada.

A pesquisa de Cheng e Yu (2008, p. 344) demonstrou que a internacionalização das pequenas e médias empresas de Taiwan não sofre pressão normativa, justificada por experiências ou relações interpessoais de CEO's anteriores ao processo de internacionalização. As relações entre os líderes são mais valorizadas do que o network com novos profissionais. Depois de sedimentada a internacionalização, houve indícios de que o network passou a ter maior relevância nessas empresas. Essa divergência pode ser justificada por fatores culturais orientais legitimados (RENAND, 2007, p. 5). Na cultura ocidental, em resposta às pressões externas, as organizações tendem a incorporar novos atores com conhecimento suficiente para tratar essas novas pressões. Desse modo, mudanças estruturais podem acontecer, com o surgimento de especialistas que contribuem para aumentar a produtividade e diversificação da força de trabalho (SCOTT, 2008, p. 433).

Outro meio usado para adotar práticas normativas são as associações de regulamentação ou certificação. Kneipp et al. (2012, p.66) identificaram em seu estudo de caso, quanto a adotar práticas de gestão para a sustentabilidade, que as organizações não atendem somente aos mecanismos de isomorfismo coercitivo via a influência formal dos órgãos governamentais, mas, também, aos mecanismos de isomorfismo normativo, na medida em que se adaptaram a normas reguladoras impostas por associações de certificação.

Cheng e Yu (2008 p. 344) demonstraram que, no início da internacionalização das pequenas e médias empresas de Taiwan, essas não sofreram pressão normativa significativa, justificada por experiências ou relação interpessoal de CEO's anteriores ao processo de internacionalização; porém, as pressões coercitiva e mimética são significativas. Essa divergência pode ser justificada por fatores culturais legitimados, pois a liderança chinesa é orientada para o benefício mútuo dos parceiros, que precisam confiar nos parceiros para atingirem o objetivo proposto. A gerência chinesa depende de conexões pessoais para encontrar pessoas chave, assistências e recursos escassos. As relações trabalhistas são personalizadas, o funcionário trabalha para o líder e não para a empresa. Entretanto, a cultura ocidental negocia com maior independência relativa ao grupo oposto, não há a valorização do desenvolvimento de relacionamento interpessoal no processo de negociação e as relações trabalhistas são despersonalizadas (CHENG; YU, 2008, p. 344, RENAND, 2007, p. 7; SLACK; HININGS, 1994, p. 821).

Mizruchi e Fein (1999) ressaltam que Dimaggio e Powell (1983) tiveram o cuidado de salientar que os três mecanismos do isomorfismo institucional envolvem processos separados, mas dois ou mais poderiam funcionar simultaneamente e seus efeitos podem não ser sempre perfeitamente identificáveis. Entre os três mecanismos do isomorfismo, o mimético atraiu a maior atenção dos pesquisadores. Embora não se possa concluir que é uma constatação universal, pois o teste se deu em revistas norte-americanas, essa preferência pode ser explicada pelo fato de que isso reflete a tendência dominante entre as organizações norte-americanas de minimizar as relações de poder e coerção, em favor de uma abordagem cognitiva de percepção e ação.

\section{Desenvolvimento da Pesquisa}

Este é um estudo de caso, em que os fatos foram observados, registrados e analisados por meio entrevistas, questionários, análise de vídeo e publicação em mídia eletrônica. Buscouse investigar a associação entre os mecanismos isomórficos e o processo de fechamento contábil no $1^{\circ}$ dia útil de uma empresa com mais de 130 anos e de representatividade global no segmento 
em que atua (YIN 2006, p. 22; GIL, 2010 p.37).

A seguir, são abordados os procedimentos e instrumentos usados para a realização do estudo de caso, como recomendado por Yin (2006). A proposta de pesquisa foi apresentada à liderança da organização. O presidente em exercício na América Latina, em conjunto com o departamento de comunicação regional, autorizou, na data da consulta, o trabalho de campo na organização.

Os instrumentos de pesquisa tiveram como base os conceitos relativos aos mecanismos do isomorfismo apresentados pela Nova Sociologia Institucional (New Institutional Sociology - NIS), um dos três enfoques da Teoria Institucional. Esses instrumentos permitem entender esses mecanismos e identificá-los no processo de fechamento contábil tempestivo. Esse processo foi possível com o uso das diferentes fontes citadas.

$\mathrm{O} 1^{\circ}$ instrumento aplicado foi o questionário com perguntas fechadas, respondidas por gerentes contábeis, gestores de tecnologia da informação e controller de localidades escolhidas para a análise. $\mathrm{O} 2^{\circ}$ foi a entrevista em profundidade com o presidente global (matriz nos EUA), responsável por antecipar o fechamento contábil para o primeiro dia útil, um ex-presidente regional (América Latina) e dois ex-funcionários que participaram da antecipação do fechamento contábil na América Latina. O questionário foi traduzido para o inglês, revisado por um tradutor e submetido para pré-teste também em inglês, revisado e enviado às unidades em outros continentes. A empresa tem sede nos Estados Unidos e a língua usada entre as unidades é o inglês. O roteiro de entrevistas teve como base perguntas semiestruturadas, o que permitiu incluir questões adicionais no decorrer da entrevista.

O método de coleta de dados históricos foi usado para comprovar o objetivo proposto por meio de um filme institucional com o objetivo de fazer a triangulação com as respostas concedidas pelos entrevistados e respondentes.

$\mathrm{O}$ roteiro de entrevistas foi enviado apenas para funcionários que fizeram parte da liderança, departamento financeiro ou tecnologia da informação durante a implantação do fechamento no primeiro dia útil. Essa foi uma limitação da pesquisa, pois nem todos os que participaram do processo estavam na organização. Foi possível contatar quatro ex-funcionários. O questionário possui perguntas cujo objetivo é identificar como os mecanismos do isomorfismo afetam ou afetaram o fechamento contábil tempestivo e a sua relação com a gestão de desempenho, contabilidade gerencial e sistemas existentes na organização. As respostas foram tricotômicas, divididas em: sim, não e não sei. A alternativa "não sei" foi pesquisada, já que o questionário foi enviado a pessoas de diferentes áreas, para mantê-lo padronizado a todos os grupos. Admitiu-se a hipótese de que perguntas específicas para a área financeira, por exemplo, podem não ser de conhecimento da área de tecnologia.

O questionário foi enviado por e-mail para sete respondentes, considerando o mesmo prazo de retorno das respostas, em todos os escritórios corporativos da organização ao redor do mundo. Isso permitiu testar se $100 \%$ dos escritórios executam ou gerenciam o processo de fechamento contábil.

Para que houvesse a triangulação com as respostas obtidas com os questionários, foram feitas quatro entrevistas em profundidade: uma com o ex-vice-presidente de planejamento financeiro global, que, posteriormente, tornou-se presidente regional na América Latina; outra com o ex CEO, líder responsável por antecipar o fechamento para o primeiro dia útil; e outras duas com ex-funcionários da área financeira, presentes à época da antecipação do fechamento para o terceiro dia, e depois, primeiro dia útil. O roteiro tem perguntas semiestruturadas, o que permitiu incluir questões adicionais, respondidas para atender ao objetivo da pesquisa.

O roteiro das entrevistas para os dois presidentes buscou identificar as motivações que os levaram a antecipar o fechamento contábil, e se durante a implantação do projeto houve a aplicação dos três mecanismos do isomorfismo. As entrevistas com os dois ex-funcionários que participaram da antecipação do fechamento contábil objetivaram a entender se, durante a 
implantação do projeto, e na manutenção do processo, houve a aplicação dos três mecanismos do isomorfismo.

Foi analisado um filme institucional, no qual o ex-CEO explica suas motivações para antecipar o fechamento para o terceiro dia útil. Outro documento usado para a triangulação foi a divulgação dos prazos de publicação determinados pelo órgão regulador norte americano. Houve a análise descritiva dos dados obtidos com os questionários. Para a análise das entrevistas, filme institucional e demais documentos públicos obtidos em mídia eletrônica fornecida por entidade reguladora, foi aplicada a análise de discurso (AD), de forma estrutural textual (GODOI, 2010). Os achados das várias análises foram triangulados para que as respostas obtidas fossem confirmadas e a conclusão do estudo não fosse enviesada por uma só perspectiva.

O método de estudo de caso limita a generalização científica; porém, permite uma análise mais profunda. Outro fator limitante foi tempo em que os funcionários fazem parte da organização, visto que nem todos estavam presentes na data em que foi adotado o fechamento tempestivo, ou não estavam no mesmo cargo.

\section{Análise dos Resultados}

Foi elaborada uma linha do tempo, pela qual é demonstrada a evolução da organização até o alcance do fechamento contábil no primeiro dia útil e a evolução da atualização dos sistemas. Segue na figura 1 essa evolução:

Figura 1 - Linha do tempo da antecipação do fechamento contábil

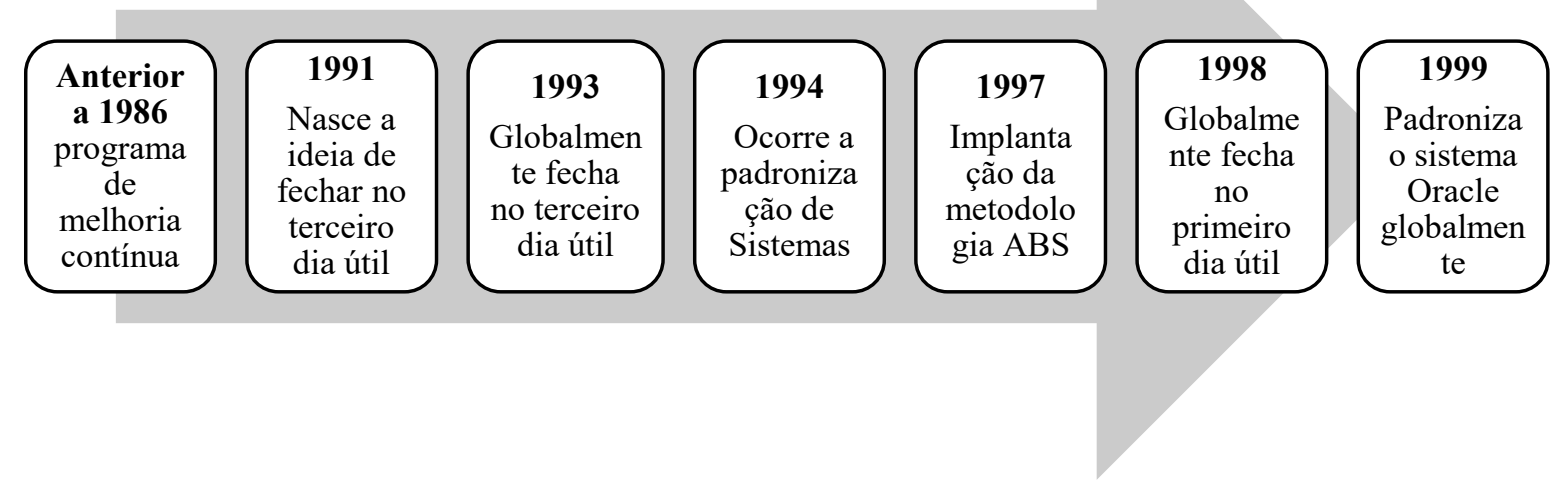

Fonte: os autores.

\subsection{Entrevistas e Filme Institucional}

Em 1987, com o objetivo de obter excelência nos processos operacionais, iniciou-se um movimento de reconhecimento do trabalho dos funcionários em todas as posições na organização, que levou ao engajamento de todos com os objetivos organizacionais. Ideias de melhoria contínua propostas pelos empregados eram analisadas e colocadas em prática; esse novo comportamento fez com que a organização atingisse resultados financeiros recordes. Houve um esforço em compartilhar a responsabilidade com todos os funcionários para que a execução da estratégia organizacional tivesse sucesso.

Houve melhorias nas áreas ligadas à produção, quanto a índices de segurança, qualidade e produtividade. Foi aí que surgiu a ideia de melhoria na área financeira. Em 1991, a empresa 
fechava em oito dias úteis e tinha 1.300 pessoas na área financeira envolvidas no fechamento contábil atuando em 43 países. O CEO definiu, junto com o controller global, que era possível antecipar o fechamento contábil para o terceiro dia útil, desde que o sistema fosse fácil de usar e seguro. O projeto foi lançado em outubro de 1991, quando se fechava em oito dias úteis; e em fevereiro de 1993, passou a fechar em três dias úteis (EDWARDS et al, 1995 p.26).

De acordo com o CEO seguinte que assumiu a organização, a sequência da estratégia em alterar a cultura da organização baseada no sistema Toyota de Produção foi mantida. Isso permitiu que a responsabilidade fosse compartilhada com o funcionário, independentemente do cargo ocupado.

Para que esse objetivo fosse alcançado, houve reestruturação de sistemas, revisão e simplificação dos procedimentos, redução de relatórios desnecessários, maior automação dos relatórios financeiros e mais engajamento das pessoas. "Em 1987 houve o início da automatização e aumento de investimentos em tecnologia nessa organização. Ideias eram premiadas, havia um movimento grande para que cada colaborador contribuísse com a melhoria contínua" (ENTREVISTADO 3). "Foi necessário criar um canal de comunicação da presidência com todos os funcionários, para aproveitar as boas ideias e recompensar as melhores" (ENTREVISTADO 4).

O modo como o objetivo foi alcançado convalida os argumentos de Zhou e AguirreUrretra (2013, p. 43). Os autores mencionam que a tempestividade das demonstrações contábeis está relacionada à melhoria da tecnologia da informação, no sentido de automatizar, integrar e padronizar processos, para atingir maior eficiência, qualidade e uniformidade, na tentativa de reduzir o tempo de conclusão das informações financeiras.

Simplificar processos não era sinônimo de desligar pessoas, "o objetivo era alocar essas mesmas pessoas que agora tinham mais tempo porque fechavam oito dias a menos, e usá-las para criar valor, seja na área de análise de resultado, de precificação, de custos, controle de despesas, etc" (ENTREVISTADO 1), de modo que contribuíssem para melhoria de processos e aumento de produtividade. A partir daí a melhoria constante nos processos fez com que a organização atingisse o fechamento no primeiro dia útil do mês seguinte, até às 18 horas do horário local de cada unidade. As demonstrações contábeis de cada país são submetidas à célula de consolidação localizada nos Estado Unidos, no escritório central da organização.

Segundo a liderança da empresa, o maior objetivo não era fechar no primeiro dia útil, mas executar as atividades diárias sem erros e sem retrabalho; ter funcionários qualificados e comprometidos em obter o melhor resultado possível com o trabalho; não ter funcionários ocupados no mês seguinte, tentando fechar números do mês anterior, mas que esses funcionários tivessem tempo disponível para fazer análises no mês corrente, que pudessem trazer resultados positivos para a organização:

Fechar mais rápido é uma consequência daquilo que se espera, como disciplina, estabilidade no processo e não ter retrabalho, não ter erro. No dia seguinte a pessoa está disponivel para analisar o resultado do mês corrente e não quarenta e cinco dias fora o mês, o que normalmente acontecia na maioria das empresas. Fechar no primeiro dia útil dá liberdade para que os tomadores de decisão possam executar as ações: tem-se o conhecimento do que aconteceu e informações para corrigir e tomar ações gerenciais. (ENTREVISTADO 2).

$\mathrm{O}$ treinamento das pessoas foi essencial, pois precisavam entender que seu trabalho era relevante para o usuário seguinte e tinham que concluir as atividades sem desperdícios. $\mathrm{O}$ balanceamento dos recursos e o nivelamento de conhecimento foram fundamentais nos departamentos para atingir o objetivo de antecipar o fechamento contábil: "O objetivo era que a área administrativa tivesse o conceito de excelência, sentissem orgulho de fazer parte da área financeira, afinal éramos a primeira empresa do índice Dow Jones que publicava o resultado" (ENTREVISTADO 1).

Mesmo com investimento em software e hardware não foi suficiente para realizar o 
fechamento no primeiro dia útil, foi necessário treinar, capacitar e engajar o usuário, pois na verdade são as pessoas que fazem o trabalho acontecer e elas devem identificar o que é necessário para melhorar o desempenho dos processos (ENTREVISTADO 4).

Em 2001, quando o CEO da organização foi questionado sobre a importância de fechar os livros contábeis em oito horas, ele respondeu que:

Não é necessário que as pessoas trabalhem por 15 dias tentando encontrar o que não deu certo. $O$ que foi feito na contabilidade que não estava certo? Ou o estoque não estava salvaguardado? É possivel concluir em 8 horas porque o trabalho é executado com perfeição todos os dias dos meses, então fechar em 8 horas é um objetivo de perfeição e não simplesmente dizer que nós fechamos em oito horas.

O CEO afirmou que o fechamento no primeiro dia útil foi possível porque a empresa perseguiu um único objetivo: execução do trabalho com perfeição, todos os dias, em todos os sentidos. E isso não era ele, mas todas as pessoas da organização. Esse era o segredo, todos os funcionários perseguindo a perfeição (EPSTEIN, 2001, p.18).

De acordo com Edwards et al. (1995, p. 26), o segredo para antecipar o fechamento relaciona-se com a qualidade do processo: "Faça o que você pode fazer e não o que deve fazer, porque quando avaliar o fechamento contábil, certamente você vai perceber que as pessoas postergam as tarefas". O segundo segredo foi não deixar as pessoas perdidas, porque "se quiser fechar no terceiro dia, não use prazos intermediários". Essa conclusão foi possível, pois a Austrália fechou no terceiro dia, antes mesmo do que a matriz. A matriz copiou o modelo de comunicação de uma subsidiária localizada na Austrália e implantou na matriz.

Quatro ações foram tomadas para que, globalmente, a empresa tivesse o mesmo processo:

1. Estabeleceu um linguajar financeiro comum;

2. Estabeleceu um data warehouse;

3. Criou centros de serviços compartilhados;

4. Reduziu o ciclo de processo em todas as atividades da organização, inclusive do fechamento contábil (EDWARDS et al, 1995, p.26).

Trata-se de um exemplo de isomorfismo intracorporativo, conforme Van der Stede (2003), em que várias formas de isomorfismo agem de maneira combinada para levar à uniformidade das práticas. Primeiro, o isomorfismo mimético da matriz incorporando uma prática organizacional da unidade da Austrália, que representa a unidade de negócio bemsucedida no processo de fechamento contábil. Nesse ponto, vale destacar que uma subsidiária pode ter uma prática diferente da orientação da matriz, por influência de variáveis contingências e aspectos da cultura nacional (VAN DER STEDE, 2003). E, posteriormente, promovendo a uniformidade da prática globalmente, por ações coercitivas que todas as subsidiárias são coagidas a aderir.

Atualmente, a organização usa o sistema integrado Oracle; todavia, a implantação do ERP em 1999 não se deu pela antecipação do fechamento contábil, pois a organização passou a fechar no primeiro dia útil em 1998. O ERP foi implantado porque os sistemas eram antiquados e diversificados em razão de incorporações de empresas que tinham sistemas próprios; outro motivo foi a falta de integração dos sistemas dentro da mesma unidade. É possível concordar com Davenport (2000, p. 165), que as unidades de negócio que usam o mesmo sistema facilitam o momento de consolidação, e organizações que operam em mercados globalizados tendem a consolidar informações para aproveitar melhor sua capacidade ao redor do mundo, para facilitar a gestão das organizações em consolidar as demonstrações contábeis, com o intuito de atender a requisitos normativos.

Para especializar a mão de obra, a organização criou centros de serviços compartilhados; e, em virtude da centralização de processamento de informações, essas devem ser separadas e agregadas inúmeras vezes. O ERP auxiliou esse processo, pois o sistema pode fazer o trabalho 
mais facilmente; porém, não é um processo simples, e cada instalação para integração de sistemas precisa de uma customização que representa custo (DAVENPORT, 2000, p. 165).

A importância que a administração atribui ao fechamento no primeiro dia útil, além da qualidade exigida nos processos de fechamento, é a redução da assimetria de informações por meio de processos confiáveis, com dados de alta qualidade e divulgação das informações em tempo adequado para responder ao mercado quando necessário:

Se fechar o balanço no dia 20, mas no dia 10 o resultado for conhecido, há uma abertura para ações criativas que podem gerar manipulação. Fechar no primeiro dia útil é uma ferramenta para evitar manipulação, e ainda permite executar análises e agir sobre os problemas ao invés de fazer contabilidade criativa (ENTREVISTADO 2).

Sob o aspecto da tempestividade, é possível concordar com Kirch, Lima e Terra (2012, p. 175), Frezatti et al. (2007, p.41) e Healy e Palepu (2001), pois a tempestividade das informações dá aos gestores habilidade para reagir sobre as incertezas econômicas e reduzir a assimetria de informações que encarece o processo decisório.

Nessa organização, os relatórios gerenciais têm o objetivo de ajudar a reduzir custos e aumentar a produtividade, considerando que os relatórios contábeis são concluídos mensalmente no primeiro dia útil, "é pra isso que fechamos no primeiro dia útil, para começar a tomar decisões que afetam os outros meses do ano" (ENTREVISTADO 2). Os relatórios contábeis são oficiais para a divulgação societária, e a partir desses relatórios consolidados, as informações gerenciais são geradas.

\subsubsection{Análise das Entrevistas Quanto ao Mecanismo Normativo}

Quanto às associações profissionais, de certificação e seleção de pessoal, como definido por Brandau et al. (2013) e Dimaggio e Powell (2005), que ocorrem pela contratação de indivíduos de organizações do mesmo segmento, pessoal com alto desempenho de um grupo restrito de instituições de treinamento, ou pelo requerimento de habilidades atreladas a cargos específicos, identificou-se que a antecipação do fechamento era inovadora, sem referência em outras organizações.

Segundo os CEO's que promoveram a mudança, fechar no primeiro dia útil não era o objetivo inicial da liderança, mas foi consequência para atingir os objetivos primordiais da organização: executar as rotinas diárias com disciplina, sem retrabalho e sem postergar a execução dos trabalhos diários. Esses objetivos têm como base a prática de melhoria contínua, que se deve às técnicas propostas pelo TPS (Toyota Production System) nas áreas produtivas e na administrativa:

O tempo das pessoas em fazer um trabalho que tem 30 dias passados é um desperdício. Recontabilizar, ver onde estava errado, etc., tudo isso é um desperdício. Dentro desse conceito a procura de eliminação de todo retrabalho é permanente, o que se almeja é a perfeição, ou seja, fazer o melhor que pode ser feito. Se você dissesse que o melhor que se pode fazer é fechar no primeiro minuto do mês, iriamos procurar executar no primeiro minuto do mês (ENTREVISTADO 2).

A proposta do TPS era eliminar desperdícios e fazer pleno uso da capacidade de mão de obra habilitada, promovendo ambientes adequados de trabalho. Trata os trabalhadores com respeito e consideração, para construir um sistema que permita aos funcionários terem liberdade de demonstrar suas habilidades (SUGIMORI ET AL., 1977, p.554).

Ao refletir sobre as propostas de novas hipóteses feitas por Felix, Guarido Filho e Gonçalves (2015, p.414), quando afirmam que "quanto mais monoprofissional for a organização (por exemplo, um escritório de advocacia, empresas de auditoria, engenharia), tanto mais homogênea e menos assimétrica será a adoção de novas práticas", infere-se que o processo de transformação do fechamento contábil na organização, provavelmente, assentou- 
se em uma quantidade restrita de profissões (controllers, contadores etc.), o que pode ter contribuído para o seu sucesso.

\subsubsection{Análise das Entrevistas Quanto ao Mecanismo Coercitivo}

A imposição do fechamento no primeiro dia útil e a mensuração dos índices de avaliação de desempenho foram identificadas como impostas formalmente pela matriz nas subsidiárias:

O CEO solicitou ao controller da época para entender como implantar excelência na área administrativa, dessa forma solicitou o limite teórico em dias para o fechamento contábil, se tivéssemos um sistema fácil de usar e sem transposição de dados. Depois de pesquisar concluiu-se que o limite teórico seria três dias. Então o CEO determinou que esse seria o objetivo (ENTREVISTADO 1).

A exigência na comparação entre o resultado orçado e o real para validação das demonstrações contábeis não ocorreu no início do processo de mudança para fechar no primeiro dia útil. Posteriormente, a administração entendeu que essa comparação seria adequada para manter a qualidade dos controles gerenciais, pois as subsidiárias têm planos orçamentários compatíveis com as políticas da matriz. Essa constatação confirma a conclusão de Dimaggio e Powell (2005) em relação a práticas contábeis, avaliações de desempenho e planos orçamentários compatíveis com as políticas da matriz adotados por subsidiárias. É possível corroborar as conclusões de Machado-da-Silva e Fonseca (2010), Van der Stede (2003) e Scott (1987), sobre a imposição de procedimentos e regras padronizados, ditados pela empresa matriz, que podem ocorrer a partir das relações de autoridade com subsidiárias.

Os aspectos relativos a ordens governamentais ou influência formal de um órgão regulador não foram identificadas, pois o prazo do fechamento implantado é inferior exigido por órgãos reguladores, conforme emenda publicada em 2005 pela SEC (Securities and Exchange Commission) relativa a esse assunto, em que o menor prazo identificado para publicações trimestrais foi de 40 dias.

A padronização de sistemas após a antecipação do fechamento para o terceiro dia foi imposta pela matriz, porque as unidades, até então, não tinham um sistema único. Entre 1993 e 1994, a matriz determinou um plano de contas global, por um único sistema da IBM, denominado Vista. De acordo com o entrevistado 3, no final da apresentação do plano para unificar o sistema uma animação, disse: "adapte-se ou morra", no sentido de que aquela era a única opção e não haveria justificativa para não padronizar o sistema, pois os demais eram arcaicos. Essa maneira marcante como o isomorfismo coercitivo age nas subsidiárias também foi encontrada na pesquisa de Ramalho (2016), sendo o mecanismo de maior influência no uso de ferramentas de gestão de custos e ERP em multinacionais alemãs que operam no Brasil.

\subsubsection{Análise das Entrevistas Quanto ao Mecanismo Mimético}

As entrevistas não revelaram evidências do mecanismo mimético diretamente relacionado ao processo de fechamento contábil, com exceção do evento da matriz copiando o modelo de uma subsidiária da Austrália. $O$ fato de não encontrar mais evidências desse mecanismo pode ser explicado porque o processo foi estruturado globalmente no mesmo ano. Ademais, os processos para o uso da informação foram padronizados para todas as unidades do grupo, por meio de um projeto desenvolvido pela controladoria global, relacionado à filosofia implantada na organização com base no Sistema Toyota de Produção. Aqui, os funcionários da área financeira implantaram o processo desde o início e criaram alternativas para os problemas específicos de cada subsidiária. O uso do Sistema Toyota de Produção revela o isomorfismo mimético, porque a organização imitou práticas já legitimadas em outra (SIEWEKE, 2014).

Outro fator que pode contribuir para criar processos próprios em cada subsidiária foi a 
falta de padronização de sistemas, pois cada unidade tinha o seu próprio. Em 1989, iniciou-se a padronização de sistemas em algumas unidades no Brasil. Em 1993, todas as unidades no Brasil tinham como sistema único o GL da IBM. Apenas entre 1993 e 1994 a matriz determinou um plano de contas global, em um único sistema da IBM denominado Vista. Ramalho (2016), pesquisando sistemas de custos gerenciais em subsidiárias alemãs, destaca que a ampla adoção do mesmo sistema também é um indício de isomorfismo mimético, corroborando Brandau et al. (2013).

A transferência de funcionários, ou mesmo a contratação de consultorias para implantar o fechamento no primeiro dia útil, não foram identificadas. Constatou-se a participação de auditoria externa na revisão dos processos implementados para validar os relatórios contábeis. Durante a pesquisa, uma empresa visitou um dos centros de serviço compartilhado para entender como funciona o processo de fechamento. Essa empresa tem interesse em antecipar seu fechamento, que acontece 45 dias posteriores à data fim do exercício fiscal. A organização foi usada como modelo por outra, o que foi conformado pelas entrevistas, provavelmente, formando uma rede de isomorfismo, conforme Beuren, Fachini e Nascimento (2010), analisando as funções de controladoria das empresas familiares têxteis de Santa Catarina. Contudo, a organização não imitou outras em relação ao fechamento no primeiro dia útil.

\subsection{Questionários}

A seguir, são apresentadas as perguntas e a consolidação das respostas obtidas com os questionários enviados aos escritórios da organização. As respostas estão agrupadas em quatro divisões relativas ao estudo dos mecanismos do isomorfismo normativo, coercitivo e mimético, e por último, avaliação de desempenho.

\subsubsection{Análise dos Questionários em Relação ao Isomorfismo Normativo}

Com base nas definições de Dimaggio e Powell (2005, p. 80), corroboradas por Brandau et al. (2013, p. 473), três questões foram levantadas para analisar a associação do mecanismo normativo em relação a profissões, associações profissionais ou de certificação e seleção de pessoas associados ao processo de antecipação do fechamento contábil para o primeiro dia útil. Seguem na tabela 2 as três perguntas relativas ao mecanismo normativo.

Tabela 02 - Questões e respostas relacionadas ao mecanismo normativo

\begin{tabular}{|c|c|c|c|c|}
\hline \multicolumn{2}{|r|}{ Mecanismo Normativo } & \multicolumn{3}{|c|}{ Quantidade de Respostas } \\
\hline Aspectos & Questões & Sim & Não & $\begin{array}{l}\text { Não } \\
\text { sabe }\end{array}$ \\
\hline Profissões & $\begin{array}{l}\text { 1. Para que o fechamento contábil aconteça no primeiro dia } \\
\text { útil, você recebeu ou leu alguma instrução ou orientação } \\
\text { de algum conselho profissional como, por exemplo, CFC } \\
\text { ou CPA? }\end{array}$ & & 7 & \\
\hline Seleção de pessoas & $\begin{array}{l}\text { 2. Na empresa em que você trabalha, algum funcionário ou } \\
\text { especialista que já possuía experiência em empresas que } \\
\text { tinham o fechamento no primeiro, foi contratado para } \\
\text { que o fechamento no primeiro dia útil fosse devidamente } \\
\text { implantado? }\end{array}$ & & 7 & \\
\hline $\begin{array}{l}\text { Associações de } \\
\text { regulamentação } \\
\text { ou certificação }\end{array}$ & $\begin{array}{l}\text { 3. O processo de fechamento no primeiro dia útil foi } \\
\text { estruturado para atender a necessidade de algum órgão } \\
\text { regulador (SEC, Fisco etc)? }\end{array}$ & & 7 & \\
\hline
\end{tabular}


As três questões não tiveram aceitação de nenhum dos aspectos anteriormente mencionados em relação ao mecanismo normativo. Esse achado alinha-se parcialmente com os resultados de Ramalho (2016), que comprovou poucas evidências da influência normativa nos sistemas de custos gerenciais das subsidiárias alemãs, E Beuren e Dallabona (2013), que encontraram pouca influência do isomorfismo normativo nas atividades operacionais das empresas contábeis de Santa Catarina.

\subsubsection{Análise dos Questionários em Relação ao Isomorfismo Coercitivo}

Com base nas definições de Dimaggio e Powell (2005, p. 77), seis questões foram levantadas para analisar a associação do mecanismo coercitivo em relação a pressões formais e informais exercidas por uma organização sobre outra em uma condição de dependência, ordens governamentais ou influência formal de um órgão regulador sobre o processo de antecipação do fechamento contábil para o primeiro dia útil. Essas perguntas foram analisadas sob duas perspectivas: a $1^{\mathrm{a}}$ sob a imposição do fechamento no primeiro dia útil, a $2^{\mathrm{a}}$, a mensuração dos índices de avaliação de desempenho. Seguem na tabela 3 as seis perguntas relativas ao mecanismo coercitivo.

Tabela 3- Questões relacionadas ao isomorfismo sob o mecanismo coercitivo

\begin{tabular}{|c|c|c|c|c|}
\hline \multicolumn{2}{|r|}{ Mecanismo Coercitivo } & \multicolumn{3}{|c|}{$\begin{array}{l}\text { Quantidade de } \\
\text { Respostas }\end{array}$} \\
\hline Aspectos & Questões & Sim & Não & $\begin{array}{l}\text { Não } \\
\text { sabe }\end{array}$ \\
\hline \multirow{4}{*}{$\begin{array}{c}\text { Pressões formais e } \\
\text { informais exercidas } \\
\text { por uma } \\
\text { organização sobre } \\
\text { outra em condição } \\
\text { de dependência. }\end{array}$} & $\begin{array}{l}\text { 4. A prática de se comparar o resultado realizado com o } \\
\text { forecast no primeiro dia útil é imposta pela empresa } \\
\text { Matriz? }\end{array}$ & 6 & 1 & \\
\hline & $\begin{array}{l}\text { 5. A análise de variação do balanço e resultado financeiro } \\
\text { entre o real e o forecast, no primeiro dia útil oportuniza aos } \\
\text { gestores decisões para melhoria de desempenho? }\end{array}$ & 7 & & \\
\hline & $\begin{array}{l}\text { 6. A análise de variação entre o real e o forecast no primeiro } \\
\text { dia útil é uma exigência da Matriz para validação das } \\
\text { demonstrações contábeis? }\end{array}$ & 7 & & \\
\hline & $\begin{array}{l}\text { 7. Os rituais para uso da informação contábil gerada no } \\
\text { primeiro dia útil de cada mês são padronizados para todas } \\
\text { as subsidiárias de acordo normas da Matriz? }\end{array}$ & 6 & 1 & \\
\hline $\begin{array}{c}\text { Ordens } \\
\text { governamentais } \\
\text { impõem a } \\
\text { conformidade entre } \\
\text { os atores afetados, } \\
\text { seja individual ou } \\
\text { coletivo. }\end{array}$ & $\begin{array}{l}\text { 8. Por divulgar o balanço publicamente e ser uma empresa } \\
\text { americana financeiramente representativa, o governo de } \\
\text { seu país solicitou de alguma forma que a organização } \\
\text { antecipasse a publicação do balanço e por esse motivo foi } \\
\text { necessário realizar o fechamento no primeiro dia útil? }\end{array}$ & & 6 & 1 \\
\hline $\begin{array}{l}\text { Influência formal } \\
\text { de um órgão } \\
\text { regulador. }\end{array}$ & $\begin{array}{l}\text { 9. O processo de fechamento no primeiro dia útil foi imposto } \\
\text { por algum órgão regulador (ex: SEC, Fisco, CVM, etc)? }\end{array}$ & & 7 & \\
\hline
\end{tabular}

A quarta questão permite analisar a perspectiva de mensuração dos índices de avaliação de desempenho, pelo pressuposto de que a prática de comparar o resultado realizado com o orçamento no primeiro dia útil foi imposta pela matriz. Seis respondentes concordaram que a comparação foi imposta pela matriz; assim é possível pactuar com a afirmação de MachadoDa-Silva e Fonseca (2010, p. 15), quanto à imposição de procedimentos e regras padronizados ditados pela matriz, que podem ocorrer a partir das relações de autoridade.

A imposição em comparar o resultado financeiro entre o real e o orçado é pertinente 
quando vinculada com a concordância dos sete respondentes na quinta questão, sobre o fato de que a análise no primeiro dia útil dá aos gestores a oportunidade de decidir em tempo real meios de melhoria de indicadores de desempenho. Essa afirmação corrobora Moores e Yuen (2001, p. 355 e 357), quanto à afirmação de que os sistemas de informações contábeis devem prover informações tempestivas e acuradas para facilitar o esforço de controlar custos, mensurar e melhorar a produtividade. Ademais, criar melhorias no processo de produção, pois a relevância e a confiabilidade das informações dependem da tempestividade de sua divulgação.

A sexta questão teve a concordância de sete dos respondentes quanto à exigência da matriz para validar as demonstrações contábeis, por meio de análise de variação entre o real e o orçado no primeiro dia útil. Conclui-se que as demonstrações contábeis agregadas às análises gerenciais e os relatórios contábeis ajudam as organizações a reduzir custos e aumentar a produtividade, pois trazem informações relevantes e tempestivas para auxiliar os gestores na eficiência de processos. Se a comparação do orçamento com o real é feita no primeiro dia útil pela organização para validar as demonstrações contábeis, pode-se dizer que as demonstrações suportam as operações e estratégias das organizações. $\mathrm{O}$ orçamento pode ser um instrumento norteador das estratégias empresariais, capaz de prever os resultados das ações dos vários atores (SANTANA et al., 2009, p. 214).

De acordo com as características expostas por Scott (2008, p.430) e Dimaggio e Powell (2005, p. 77), quanto às ordens governamentais e órgãos reguladores como exemplo de isomorfísmo coercitivo, não foram encontrados indícios de coerção pelo governo norteamericano e de órgãos reguladores para o fechamento contábil no primeiro dia útil (questões 8 e 9). Beuren e Dallabona (2013) encontraram forte influência do isomorfismo coercitivo nas operações das empresas de contabilidade de Santa Catarina, dada a dependência que essas organizações têm dos órgãos reguladores. Assim, infere-se que, provavelmente, a prática gerencial do uso tempestivo da informação contábil não sofre influência de forças governamentais e órgãos reguladores; mas, de alguma forma, contribui para atender a normas e leis que devem ser observadas, tanto pela matriz como pelas subsidiárias.

\subsubsection{Análise dos Questionários em Relação ao Isomorfismo Mimético}

Com base nas definições de Dimaggio e Powell (2005 p. 78), sete questões foram levantadas para identificar se há associação do mecanismo mimético sobre o processo de antecipação do fechamento contábil para o primeiro dia útil. As perguntas foram agrupadas em três aspectos: quando uma organização toma outra como exemplo, em face de um problema com resposta incerta; quando há transferência e rotatividade de funcionários, ou pela contratação de consultorias; e quando as organizações analisam seus concorrentes e imitam práticas consideradas bem-sucedidas e legitimadas. Seguem na tabela 4 as sete perguntas relativas ao isomorfismo mimético.

Quanto à hipótese de uma organização tomar outra como exemplo, em face de um problema com resposta incerta, como relatado por Dimaggio e Powell (2005 p.78), foram elaboradas três perguntas. A questão procura entender se o processo de fechamento no primeiro dia útil foi estruturado pela matriz e replicado paras as subsidiárias; dois respondentes entendem que sim e cinco que não foi estruturado pela matriz e replicado para as subsidiárias.

A décima primeira pergunta buscou entender se o uso da informação contábil gerada no primeiro dia útil de cada mês é específico para cada unidade; cinco respostas foram obtidas de que cada unidade é livre para determinar como usar a informação gerada no primeiro dia útil, uma resposta foi negativa e outra não soube responder. Para identificar se, depois de implantado o fechamento no primeiro dia útil, houve interações no sentido de imitar outra organização, a décima segunda pergunta abordou se, depois de concluído o fechamento no primeiro dia útil, há reuniões entre as unidades para trocar experiências de como resolver possíveis falhas do 
fechamento; essa questão teve seis respostas positivas e uma negativa.

Tabela 4 - Questões e respostas relacionadas ao isomorfismo sob o mecanismo mimético

\begin{tabular}{|c|c|c|c|c|}
\hline \multicolumn{2}{|r|}{ Mecanismo Mimético } & \multicolumn{3}{|c|}{ Quantidade de Respostas } \\
\hline Aspectos & \begin{tabular}{|c|} 
Questões \\
\end{tabular} & Sim & Não & Não sabe \\
\hline \multirow{3}{*}{$\begin{array}{c}\text { Quando uma } \\
\text { organização toma outra } \\
\text { como exemplo, em face } \\
\text { de um problema com } \\
\text { resposta incerta. }\end{array}$} & $\begin{array}{l}\text { 10.O processo de fechamento no primeiro dia útil foi } \\
\text { estruturado pela Matriz e replicado paras as } \\
\text { subsidiárias? }\end{array}$ & 5 & 2 & \\
\hline & $\begin{array}{l}\text { 11. Os rituais para uso da informação contábil gerada } \\
\text { no primeiro dia útil de cada mês são específicos } \\
\text { para cada subsidiária? }\end{array}$ & 5 & 1 & 1 \\
\hline & $\begin{array}{l}\text { 12.Depois de concluído o fechamento no primeiro dia } \\
\text { útil, é feita alguma reunião com outras localidades } \\
\text { para trocar experiências de como solucionar } \\
\text { possíveis falhas do processo de fechamento? }\end{array}$ & 6 & 1 & \\
\hline $\begin{array}{l}\text { Transferência e } \\
\text { rotatividade de } \\
\text { funcionários, } \\
\text { diretamente ou por } \\
\text { contratação de } \\
\text { consultorias. }\end{array}$ & $\begin{array}{l}\text { 13.O processo de fechamento no primeiro dia útil foi } \\
\text { estruturado com o auxílio de alguma consultoria? }\end{array}$ & & 7 & \\
\hline \multirow{3}{*}{$\begin{array}{l}\text { As organizações analisam } \\
\text { seus concorrentes e } \\
\text { imitam práticas } \\
\text { consideradas bem- } \\
\text { sucedidas e legitimadas. }\end{array}$} & $\begin{array}{l}\text { 14. Você conheceu outra empresa anteriormente que } \\
\text { implantou o fechamento do balanço no primeiro } \\
\text { dia útil? }\end{array}$ & & 7 & \\
\hline & $\begin{array}{l}\text { 15.Essa organização já foi usada como modelo por } \\
\text { outras empresas para a implantação do fechamento } \\
\text { no primeiro dia útil? }\end{array}$ & 5 & 1 & 1 \\
\hline & $\begin{array}{l}\text { 16.O processo de fechamento no primeiro dia útil foi } \\
\text { estruturado a partir das práticas já adotadas por } \\
\text { outra(s) empresa(s)? }\end{array}$ & & 7 & \\
\hline
\end{tabular}

Essas três respostas se alinham à afirmação de Dimaggio e Powell (2005, p.78), de que a imitação se dá pela incerteza na solução de problemas, identificada na décima segunda questão. É possível corroborar Dimaggio e Powell $(2005$, p.78) quanto à comunicação entre as subsidiárias e a matriz, que ocorre para encontrar o melhor método de identificar e solucionar certos problemas. Destarte, não é preciso iniciar a criação de um modelo desde o estágio inicial e essa pode ser uma solução econômica, pois a identificação e resolução dos problemas pode ser antecipada.

A décima terceira questão trata da hipótese de ter havido a contratação de consultorias para a implantação do fechamento no primeiro dia útil. Todos os respondentes confirmaram que não houve contratação de consultorias; assim não foi possível constatar o aspecto relativo a essa contratação para antecipar o fechamento no primeiro dia útil. Machado-da-Silva e Fonseca (2010, p. 16) explica que esse é um meio de incorporar modelos pela imitação de arranjos estruturais e procedimentos, que buscam reduzir a incerteza causada por problemas tecnológicos, objetivos conflitantes e exigências institucionais.

As organizações analisam seus concorrentes e imitam práticas consideradas bemsucedidas e legitimadas. Desse modo, a décima quarta pergunta buscou identificar se outra empresa anteriormente implantou o fechamento do balanço no primeiro dia útil, para entender se, no momento da antecipação do fechamento, seria possível imitar outra organização. Nenhum dos entrevistados declarou conhecer qualquer organização com tal prática; por isso, a décima sexta questão teve todas as respostas negativas.

A décima quinta questão teve cinco respostas positivas e uma negativa, e um 
respondente não soube. Essas respostas indicam que organizações sem experiência tendem a imitar o comportamento da mais experiente. Isso corrobora a conclusão de Sieweke (2014, p 30 e 31), de que a imitação ocorre quando os atores entram em um novo campo social, pois os recém-chegados tendem a imitar o comportamento dos mais experientes.

Dois efeitos devem aqui ser considerados: o primeiro é o comportamental, em que se observa a imitação de outros atores; o segundo é a influência na cognição humana, em que esquemas de percepção e ação são construídos e afetarão as futuras práticas destes atores. Quando novas práticas forem legitimadas, há uma forte tendência à imitá-las por novos atores. Concorda-se com Dimaggio e Powell (2005, p.78) que a imitação pode ser uma solução econômica, pois antecipa a identificação de possíveis problemas, e não há a necessidade de criar um modelo desde o estágio inicial.

As entrevistas e os questionários permitiram identificar que a antecipação do fechamento era inovadora e sem referência em outras organizações, que se confirmou por meio de documentos analisados. Dessa forma não foram encontradas evidências do mecanismo normativo no processo de antecipação do fechamento contábil da organização.

Quanto ao isomorfismo coercitivo, pressões formais da matriz sobre as subsidiárias foram encontradas em entrevistas e questionários aplicados quanto à exigência da matriz na comparação entre o resultado orçado e o real, para validar as demonstrações contábeis, e sobre a padronização dos rituais para uso da informação contábil gerada no primeiro dia útil de cada mês, para todas as subsidiárias, de acordo com as normas da matriz. Pressões formais da matriz sobre as subsidiárias foram encontradas nas entrevistas quanto à padronização de sistemas, logo após a antecipação do fechamento para o terceiro dia.

A triangulação dos resultados revelou que as unidades trocaram experiências entre si para encontrar o melhor método de identificar e resolver certos problemas; por isso, não houve necessidade de criar um modelo desde o estágio inicia. Essa pode ser uma solução econômica, pois a identificação e dissolução dos problemas pode ser antecipada. Mediante as entrevistas, o isomorfismo mimético foi identificado sob o aspecto de que as organizações analisam seus concorrentes e imitam práticas consideradas bem-sucedidas e legitimadas. $\mathrm{Na}$ organização objeto de estudo, uma metodologia de melhoria contínua denominada ABS (A Business System) foi adotada e teve como base o TPS (Toyota Production System), adaptado à realidade da organização.

Machado da Silva e Fonseca (2010, p.18) define que a incorporação de conhecimentos oriundos da percepção externa permite que os esquemas interpretativos sejam direcionados à padronização das atividades dentro da estrutura, pela elaboração dos padrões interativos organizacionais. Isso conduz ao entendimento de que o (TPS) Sistema Toyota de Produção foi incorporado, ajustado e padronizado dentro da estrutura organizacional, pois a compreensão e internalização do significado das práticas organizacionais pressupõe a capacidade dos atores reordenarem a estrutura do curso da interação, segundo seus valores e interesses.

\section{Conclusão}

Nesta pesquisa, analisou-se como os mecanismos isomórficos influenciaram o processo de fechamento contábil para gerar informações contábeis tempestivas em uma organização. $\mathrm{O}$ objetivo foi atendido, evidenciando como os mecanismos do isomorfismo coercitivo e mimético influenciaram o processo de fechamento contábil desde sua concepção. Não foram encontradas evidências do isomorfismo normativo; assim, é possível confirmar que não há relação entre os três mecanismos do isomorfismo, distintos e que não reforçam a existência um do outro.

O isomorfismo coercitivo foi encontrado em duas situações relativas às pressões formais da matriz sobre as subsidiárias: a $1^{\mathrm{a}}$ quanto à comparação entre o resultado orçado e o real como 
exigência da matriz para validar as demonstrações contábeis; a $2^{\mathrm{a}}$ sobre a pressão formal exercida pela matriz para padronizar os rituais de uso da informação contábil gerada no $1^{\circ}$ dia útil de cada mês, para todas as subsidiárias.

E com base nessa análise, foi identificado que há imposição de procedimentos e regras padronizadas ditadas pela empresa matriz, que ocorre a partir das relações de autoridade sobre organizações que se encontram em condição de dependência, assim como as práticas contábeis, avaliações de desempenho e planos orçamentários são compatíveis com as políticas da matriz adotados por subsidiárias.

O uso da informação no primeiro dia útil e a comparação dessas informações com o orçamento confirma que as informações contábeis são produzidas a tempo de serem agregadas às análises gerenciais. Ainda, que os relatórios contábeis são essenciais para a organização identificar oportunidades de reduzir custos e aumentar produtividade, pelo uso de informações tempestivas que auxiliam os gestores na eficiência de processos. Para determinar a antecipação do fechamento contábil, o CEO solicitou ao controller uma análise "de qual seria o limite teórico em dias para o fechamento contábil, se tivéssemos um sistema fácil de usar e sem transposição de dados. Depois de pesquisar concluiu-se que o limite teórico seria três dias. Então o CEO determinou que esse seria o objetivo" ( ENTREVISTADO 1).

Os três aspectos do isomorfismo coercitivo referentes a pressões formais e informais exercidas por uma organização sobre outra que se encontra em uma condição de dependência, ordens governamentais e por organizações racionalizadas às diversas arenas da vida social, conforme Dimaggio e Powell (2005, p. 77), apenas pressões formais exercidas pela matriz foram identificadas. No que se refere a ordens governamentais e órgãos reguladores, não foram identificadas associações à antecipação do fechamento contábil no primeiro dia útil.

O mecanismo mimético foi identificado durante o processo de antecipação do fechamento contábil, quando a matriz imitou uma subsidiária cujo objetivo foi reduzir a incerteza da matriz por uma prática de sucesso. Conclui-se que novas práticas legitimadas geram tendência à imitação pelos novos atores. A troca de experiências entre as subsidiárias para encontrar o melhor método de identificar e resolver certos problemas confirma que a não criação de um modelo desde o estágio inicial é uma solução econômica na identificação e resolução dos problemas, que pode ser antecipada.

A organização não imitou outras quanto ao fechamento no $1^{\circ}$ dia útil. Buscou melhorar os processos organizacionais, motivada pelo sucesso identificado em melhorias realizadas em suas áreas operacionais, de saúde e segurança. Essa mudança dos processos organizacionais é justificada por circunstâncias internas de desempenho abaixo das expectativas dos acionistas. A organização foi usada como modelo por outras, o que confirma a hipótese de que organizações sem experiência tendem a imitar o comportamento da mais experiente, e que o processo de imitação acontece quando os atores entram em um novo campo social, pois os recém-chegados tendem a imitar o comportamento dos mais experientes. Quando novas práticas forem legitimadas, há uma forte tendência à imitação dessas por novos atores.

Ficou evidente que a organização imitou uma metodologia de melhoria contínua denominada ABS (A Business System), que teve como base o TPS (Toyota Production System). Entretanto, a organização exerceu controle sobre o ambiente e adaptou a metodologia à sua realidade. Essa imitação não eliminou a autonomia da organização imitadora, que exerceu o controle sobre as condições do ambiente, visando ao alcance de seus objetivos e a manutenção de seus interesses. O Sistema Toyota de Produção (TPS) foi incorporado, ajustado e padronizado dentro da estrutura organizacional, pois a compreensão e internalização do significado das práticas organizacionais supõe a capacidade de os atores reordenarem a estrutura do curso da interação, segundo seus valores e interesses.

Por fim, não houve identificação de transferência de funcionários, ou mesmo a contratação de consultorias específicas para antecipar o fechamento no primeiro dia útil. As 
observações relacionadas ao isomorfismo coercitivo e mimético realizadas nesta pesquisa possibilitaram a inferência sobre a não relação entre os três aspectos apresentados para cada mecanismo do isomorfismo. Isso porque dois dos aspectos relacionados ao isomorfismo coercitivo não foram identificados, assim como um dos aspectos relacionados ao isomorfismo mimético.

Este estudo contribuiu para entender que a tempestividade das informações contábeis é necessária para a gestão organizacional eficaz, no modelo de gestão usado pela organização objeto de estudo que usa artefatos de contabilidade gerencial comumente discutidos, como apresentado no tópico 2 deste artigo. O entrevistado 2 diz que é por esse motivo que a organização fecha no primeiro dia útil, "para começar a tomar decisões que afetam os outros meses do ano". Outra contribuição se refere à confirmação da influência dos mecanismos isomórficos miméticos e coercitivos apresentados por Dimaggio e Powell (2005) nas práticas de contabilidade gerencial, e o efeito causado na relevância da tempestividade das informações contábeis dentro da contabilidade.

O estudo permitiu compor questões que merecem pesquisas futuras, conforme sugestões a seguir: a) entender quais foram as adaptações necessárias ao sistema TPS para uso da organização, para justificar se houve a descontextualização de suas origens, e quais foram as esferas adaptadas à realidade da organização; b) verificar a correlação entre cada aspecto dos mecanismos do isomorfismo; e c) entender se, pelo fato de identificar quatro aspectos para o mecanismo mimético, não justificaria a maior incidência de pesquisas relativas ao mecanismo mimético, assim como na pesquisa de Mizruchi e Fein (1999).

\section{Referências}

ALMEIDA, J. E. F. Qualidade da Informação Contábil em Ambientes Competitivos. 2010. 188 p. Tese (Doutorado em Ciências Contábeis) - Programa de Pós-Graduação em Ciências Contábeis, Departamento de Contabilidade e Atuária, Faculdade de Economia, Administração e Contabilidade da Universidade de São Paulo, 2010.

ALMEIDA, J. E. F.; SARLO NETO, A.; BASTIANELLO, R. F.; MONEQUE, E. Z. Alguns aspectos das práticas de suavização de resultados no conservadorismo das companhias abertas listadas na BM\&DBOVESPA. Revista de Contabilidade \& Finanças - USP, São Paulo, v. 23, n. 58, p. 65-75, jan./abr. 2012. https://doi.org/10.1590/S1519-70772012000100005

ANNI, Y. A.; KRISMIAJI. Enterprise Resource Planning Implementation and Accounting Information Quality. GSTF International Journal on Business Review, Schweis, v. 2, n. 4, p. 25-31, jul. 2013. https://doi.org/10.5176/2010-4804_2.4.247

BEUREN, I. M.; DALLABONA; L. F. Presença de mecanismos isomórficos em empresas contábeis. Revista Alcance - Eletrônica, Vol. 20 - n. 01 - p. 96-116 - jan./mar. 2013 http://dx.doi.org/10.14210/alcance.v20n1.p096-116

BEUREN, I. M.; FACHINI, G. J.; NASCIMENTO, S. Evidências de Isomorfi smo nas Funções da Controladoria das Empresas Familiares Têxteis de Santa Catarina. Revista Contemporânea de Contabilidade. UFSC, Florianópolis, ano 07, v.1, n¹3, p. 35-62, Jan./Jun., 2010. https://doi.org/10.5007/2175-8069.2010v7n13p35

BRANDAU, M.; ENDENICH, C.; TRAPP, R.; HOFFJAN, A. Institutional drivers of conformity - Evidence for management accounting from Brazil and Germany. International Business Review, n. 22, p. 466-479, 2013. https://doi.org/10.1016/j.ibusrev.2012.07.001

BRUDAN, A. Rediscovering performance management: systems, learning and integration. Measuring Business Excellence, Bradford, USA, v. 14, n. 1, p. 109-123, 2010. 
https://doi.org/10.1108/13683041011027490

CHENG, H.; YU, C. J. Institutional pressures and initiation of internationalization: evidence form Taiwanese small- and medium-sized enterprises. International Business Review, United Kingdom, n. 17, p. 331-348, 2008. https://doi.org/10.1016/j.ibusrev.2008.01.006.

COLMENARES, L. Benefits of ERP systems for accounting and financial management. Proceedings of the Academy of Information and Management Sciences, New Orleans, v. 13, n. 1, 2009.

DAVENPORT, T. H. The Future of Enterprise System-Enabled Organizations. Information Systems Frontiers. ABI/INFORM Global, v. 2, n. 2, p. 163-180, aug. 2000. https://doi.org/10.1023/A:1026591822284

DAVIS, S.; ALBRIGHT, T. The Changing Organizational Structure and Individual Responsibilities of Managerial Accountants: A Case. Journal of Managerial Issues, v. 12, n. 4, p. 446-467, 2000.

DIMAGGIO, P. J.; POWELL, W.W. A Gaiola de ferro revisitada: isomorfismo institucional e racionalidade coletiva nos campos organizacionais. Revista de Administração de Empresas, v. 45, n. 2 , p. $74-89,2005$.

EDWARDS, E.; WULFF, J. K.; AMETT, L. A.; HICKIE, D. W. L. et. al. The Controller's New Agenda. Financial Executive, v. 11, n. 1, p. 25-31, jan./fev. 1995.

EPSTEIN, G. Alcoa's angels. Barron's, v.81, n.10, p.18, 05 mar. 2001.

FELIX, I. M. N.; GUARIDO FILHO, E. R.; GONÇALVES, S. A. Isomorfismo normativo versus isomorfismo mandatório na adoção de práticas organizacionais. Organizações em contexto, São Bernardo do Campo, v. 11, n. 22, jul.-dez. 2015. DOI:

http://dx.doi.org/10.15603/1982-8756/roc.v11n22p383-419

FREZATTI, F.; GUERREIRO, R.; AGUIAR, A. B.; GOUVÊA, M. A. Análise do Relacionamento entre a Contabilidade Gerencial e o Processo de Planejamento das Organizações Brasileiras. Revista de Administração Contemporânea, $2^{\mathrm{a}}$ ed., p. 33-54, 2007. http://dx.doi.org/10.1590/S1415-65552007000600003

GIL, A. C. Como elaborar projetos de pesquisa. 5. ed. São Paulo: Atlas, 2010.

GODOI, C. K. Perspectiva de análise do discurso nos estudos organizacionais. In: GODOI, C. K.; BANDEIRA-DE-MELLO, R.; SILVA, A. B. Pesquisa qualitativa em estudos organizacionais: paradigmas, estratégias e métodos. 2. ed. São Paulo: Saraiva, 2010.

GUERREIRO, R.; FREZATTI, F.; LOPES, A. B.; PEREIRA, C. A. O entendimento da contabilidade gerencial sob a ótica da teoria institucional. Revista Organizações e Sociedades, v. 12, n. 35, p. 91-106, out./dez. 2005. http://dx.doi.org/10.1590/S198492302005000400005

GUERREIRO, R. A Abordagem Institucional na Contabilidade Gerencial. Revista Contabilidade e Finanças, São Paulo, n. 40, p. 3-6, jan./abr., 2006. http://dx.doi.org/10.1590/S1519-70772006000100001

HEALY, P. M.; PALEPU, K.G. Information asymmetry, corporate disclosure, and the capital markets: A review of the empirical disclosure literature. Journal of Accounting and Economics, Boston, p. 405-440, 2001. https://doi.org/10.1016/S0165-4101(01)00018-0

KIRCH, G.; DE LIMA, J. B. N.; TERRA, P. R. S. Determinantes da Defasagem na Divulgação das Demonstrações Contábeis das Companhias Abertas Brasileiras. Revista Contabilidade e Finanças -USP, São Paulo, v. 23, n. 60, p. 173-186, set./dez. 2012. 
https://doi.org/10.1590/S1519-70772012000300003

KNEIPP, J. M.; GOMES, C. M.; BICHUETI, R. S.; MACCARI, E. A. Gestão para a Sustentabilidade em Empresas do Setor Mineral. Revista de Ciências da Administração, v. 14, n. 33, p. 52-67, ago. 2012. https://doi.org/10.5007/2175-8077.2012v14n33p52

MACCARI, E. A.; SAUAIA, A. C. A. Aderência de sistemas de informação na tomada de decisão: um estudo multicaso com jogos da empresa. Revista de Gestão da Tecnologia e Sistemas de Informação, São Paulo, v. 3, n. 3, p. 371-388, 2006.

https://doi.org/10.5007/2175-8077.2012v14n33p52

MACHADO-DA-SILVA, C. L.; FONSECA, V. S. DA. Estruturação da estrutura organizacional: o caso de uma empresa familiar. Revista de Administração

Contemporânea, Curitiba, Ed. Especial, art. 1, p. 11-32, 2010.

http://dx.doi.org/10.1590/S1415-65552010000600002

MIZRUCHI, M. S.; FEIN, L. C. The Social Construction of Organizational Knowledge: A Study of the Uses of Coercive, Mimetic, and Normative Isomorphism. Administrative Science, v. 44, p 653-683, 1999. https://doi.org/10.2307/2667051

MOORES, K., YUEN, S. Management accounting systems and organizational configuration: a life-cycle perspective. Accounting, Organizations and Society, v. 26, p.351-389, 2001. https://doi.org/10.1016/S0361-3682(00)00040-4

OLETO, R.R. Percepção da qualidade da informação. Ciência da Informação. Brasília, v. 35, n. 1, p. 57- 62, jan./abr. 2006. http://dx.doi.org/10.1590/S0100-19652006000100007

PAIM, I.; NEHMY, R. M.Q; GUIMARÃES, C. G. Problematização do conceito"Qualidade" da Informação. Ciência da Informação. Belo Horizonte, v. 1, n. 1, p. 111-119, jan./jun. 1996.

RAMALHO, L. D. F. Estudo sobre sistemas de custos gerenciais de subsidiárias alemãs em operação no Brasil: um enfoque da nova teoria institucional. Dissertação (Mestrado).

Universidade de São Paulo, 2016.

RENAND, F. Cultura Gerencial Chinesa versus Cultura Ocidental. Revista de Ciências da Administração, Santa Catarina, v. 9, n. 17, jan/abr. 2007. https://doi.org/10.5007/\%25x

SANTANA, G. A. S.; MÁRIO, P. C.; SEDIYAMA, M. Y. N.. Análise do orçamento sob uma abordagem teórica da perspectiva institucional. Revista Contabilidade e Controladoria (RC\&C), Curitiba, v. 1 n. 3, p. 200-216, set/dez. 2009.

http://dx.doi.org/10.5380/rcc.v1i3.20659

SCOTT, W. R. The Adolescence of Institutional Theory. Administrative Science Quarterly, v. 32, n. 4, p. 493-511, dez. 1987.

SCOTT, W.R. Institutions and Organizations. New Jersey: Sage, 2001.

SCOTT, W. R. Approaching Adulthood: The Maturing of Institutional Theory. Springer

Science, v. 37, n. 5, p. 427-442, out. 2008. https://doi.org/10.1007/s11186-008-9067-z

SIEWEKE, J. Imitation and Processes of Institutionalization - Insights from Bourdieu's Theory of Practice. Schmalenbach Business Review, Düsseldorf, Alemanha, p. 24-42, jan. 2014. https://doi.org/10.1007/BF03396868

SLACK, T.; HININGS, B. Institutional Pressures and Isomorphic Change: Na Empirical Test. Organization Studies, v. 15, n. 6, p. 803-827, 1994.

SUGIMORI, Y.; KUSUNOKI, K.; CHO, F.; UCHIKAWA, S. Toyota Production System and 
Kanban System: materialization of just-in-time and respect-for-human system. International Journal of Production Research, v. 15, n. 6, p. 553-564, 1977.

VAN DER STEDE, W. A. The effect of national culture on management control and incentive system design in multi-business firms: evidence of intracorporate isomorphism. European Accounting Review v. 12, n 2, p. 263-285, 2003. https://doi.org/10.1080/0963818022000009859

VICENTE, C. S.; MAJOR, M. J.; PINTO, J. C. Estudo da Mudança nas Práticas de Controlo de Gestão em Portugal. Contabilidade \& Gestão, v. 10, p. 9-40, mar. 2011.

WAGNER, J. Performance measurement systems in $20^{\text {th }}$ Century: a historical perspective into the trends during the 80's and 90's. International Journal on GSTF Business Review, Schweis, v. 1, n. 3, p. 56-61, Jan. 2012. https://doi.org/10.5176/2010-4804_1.3.95

YIN, R. K. Estudo de caso: planejamento e métodos. 3. ed. Porto Alegre: Bookman, 2006.

ZHOU, M.; AGUIRRE-URRETA, M. Financial Closing Time and Cost of Equity: The Role of Senior Information Systems Executives. Review of Business Information Systems, v. 17, n. 1, p. 41-52, 2013. https://doi.org/10.19030/rbis.v17i1.7583

ZUCKER, L.; TOLBERT, P. S. Institutional sources of change in the formal structure of organizations: the diffusion of civil service reform, 1880-1935. Administrative Science Quarterly, v. 28, p. 22-39, 1983. 